\title{
Questioning Abenomics and a Keynesian Approach to Japan's Deflation Problem via Input-Output Analysis
}

ONUR BIYIK ( $\sim$ biyik-onur@fuji.waseda.jp )

Waseda University

\section{Research Article}

Keywords: Leontief Method, GDP, Employment, Abenomics, Keynesian, Japan's Economy

Posted Date: August 4th, 2021

DOI: https://doi.org/10.21203/rs.3.rs-777946/v1

License: (c) (i) This work is licensed under a Creative Commons Attribution 4.0 International License.

Read Full License 


\section{Abstract}

Japan's economy has had chronic deflation and high public debt problems so that it has been trying to handle its problems based on either the demand-side or the supply-side for more than two decades. This paper suggests that a perspective of Keynesian-inspired Japanese economic policy may positively impact a specific part of the economy such as demand-side solutions, as mentioned in Keynes' theory. The Japanese economy is examined by applying the Input-Output $(I / O)$ method in which the aggregated eleven-sector is arranged by using statistical data from the Ministry of Economy, Trade, and Industry (METI). Firstly, our analysis focuses mainly on the updated 2012 domestic l/O table in order to understand the Japanese economic structure by examining final demand elements and eleven sectors, associated with the Leontief method. Secondly, this paper then investigated comparing with Abenomics representing by a mix of the new Keynesian and neoliberal policies in order to comparatively analyzed between the current economic structure and the economic policy and lastly provided some discussions to figure out in perspective of how to solve some economic issues. Therefore, not only did this paper delineate three scenarios/keys through dominant final demand which account for the public consumption expenditures (PUCE) and the public gross fixed capital formation (PUGFC); the target of the growth rate -the automobile sector through PUGFC-, the employment rate -the commerce sector through PUCE-, and the import rate -the commerce sector through PUCE- based on the results of the data analyzed, but also comparatively examined Abenomics in order to provide some possible policy paths which highlight the demand-side remedies for the economic issues; structural reform in the fiscal sustainability, mainly wage increase (especially low and middle incomes), working practice (bringing back the mutual work environment), and fair tax system.

\section{Introduction}

Japanese economic development historically had rapid economic growth decades during the 1960 s to 1980 s and faced abruptly lost decades during the 1990s to 2000s. In general, Japan's economy has become to be a highly developed and a market-oriented economy, which accounts for the third-largest nominal GDP and the second-largest developed economy in the world (IMF, 2016). Japan has become an important bilateral and multilateral Free Trade Agreements (FTAs) supporter such as involving the Comprehensive and Progressive Agreement for Trans-Pacific Partnership (CPTPP) and European Union (EU) during the Abenomics period, as they were interested in FTAs in the late 1990s (Solis \& Urata, 2018). The country, however, has faced problems domestically (aging and deflation) as well as internationally increasing competition from China and South Korea. Accordingly, the government has been working to solve those problems through not only monetary and fiscal policies but also through some regulations/deregulations in the market.

The Abe-led government initiated from the end of 2012 published its economic policy, the so-called Abenomics, which is represented by three arrows; (1) fiscal expansion, (2) monetary easing, and (3) structural reform by a mix of the new Keynesian remedies in the financial and monetary policies boosting domestic demand and gross domestic product (GDP) growth and neoliberal policies in terms of structural 
reform increasing competition, reforming labor markets, and expanding trade partnerships (GOJ, 2019). Some scholars argue that these policies not only could cause an inequality, environmental issues, and an insecure system for employees (Shibata, 2017) but may also destabilize the Japanese economy (via fiscal deficit and hyperinflation). As an example, whereas unconventional monetary policy has not worked and has not caused inflation to rise under the zero-interest rate ${ }^{1}$ and sticky inflation rate (Miyao \& Okimoto, 2017), exchange rate, the oil price, and the wage index have had a significant correlation with the price index (Yoshikawa, et al., 2015). On the other hand, fiscal policy shock has had the positive effect of GDP and consumption (Mino, 2016; Morita, 2017) while Japanese government debt is not sustainable (Armstrong \& Okimoto, 2016) and may cause a fiscal crisis because of the high public debt (Ning, 2018). In general, scholars expressed that Abe's policies are essentially the same as Koizumi-led government, have a lack of alternative growth engines (Shibata, 2017), has solved some productivity-related issues (Ito, et al., 2018), and has been, however, failing to address inequality and environmentally related issues (Lechevalier \& Monfort, 2018). In that context, this study analyzes the Japanese economy by applying updated $2012 \mathrm{l} / \mathrm{O}$, investigates how to solve some Japanese economic problems such as growth engines through strategic demand and sector, and proposes the Keynesian-inspired Japanese economic policy to deal with deflation which highlights the demand-side remedies such as structural reform in income, working practice, and tax system, as mentioned in Keynes' theory.

With reference to the argument concerning Abenomics policy and $\mathrm{I} / \mathrm{O}$ analysis in Japanese studies, scholars studied Japanese creative industry sectors (Zuhdi, et al., 2013), Japanese livestock sector (Zuhdi, et al., 2014), Japanese energy sectors (Zuhdi, 2015), and Japan's information and communication technology (ICT) sectors (Zuhdi \& Prasetyo, 2014) as a sectoral ceases. Moreover, there are few I/O analysis regarding the perspective of Japanese economic growth and policy; Japan's economic growth and policymaking (Shishido, 2004), technological change and accumulated capital (Kuroda \& Nomura, 2004), the economic effect of the medical care expenditure (Yamada \& Imanaka, 2015). Also, Shishido and Nakamura (2019) recently investigated just growth alternatives in Abenomics by a dynamic econometric model with I/O system and forecasted some scenario projects from 2011 to 2020 . However, the objective of this study is to introduce a method of the competitive Leontief approach (in) using -first time- updated 2012 domestic I/O data in order to figure out most dominant demand and sector based on targeted macro variables and quantitatively investigated Abenomics, three arrows, in order not only to understand current economic structure and but also to evaluate comparatively recent economic policy, in contrast with previous research. In general, this paper suggests answers to the following questions: what is Japan's key/dominant demand and sector for not only the benefit of the growth strategy based on selected macro variables but also organizing their economy in order to become either a more innovative country or a service country regarding result of the analysis; has current Abenomics remedy for economic problems in Japan recovered/succeed?

This paper is organized as follows: after the introduction, the second section will portray the data and methodology. The third section will comprehensively analyze the Japanese sectors with the use of the I/O table which highlight three macro variables by disaggregating the final demand items to the eleven 
respective sectors and investigate the strategic final demand and sector based on selected macro variables in order to present three figures: the target of the growth rate, the employment rate, and the import rate. The fourth section will discuss the potential risks of and possible solutions for Abenomics followed by concluding remarks about the implications of this study.

\section{Data And Methodology}

The updated 2012 domestic I/O table has been created from the sectoral research and surveys run by the Ministry of Economy, Trade, and Industry (METI). In this paper, 53 sectors identified by METI was aggregated into 11 groups such as agriculture, forestry, and fishery, mining, manufacturing, industrial machinery, computers and electronic equipment, automobiles, construction, commerce, finance and insurance, other business services, and services (Appendix 8). This means that the sectors are categorized based on the similarity of production functions and goods properties, substituted or complementary, and the use of one sector production as an input to another sector (Miller \& Blair, 2009; METI, 2018).

To analyze all sectors together as well as each sector respectively, this paper made the input coefficient matrix, the Leontief matrix, and the inverse matrix. With the calculated technical coefficients, this study examined variation in final demand items, which are analyzed both together and separately with effects on the three macro factors. Moreover, the three macroeconomic variables are also studied together and separately. It should be noted that the employment point in I/O carried out forecasting of the working time of the employees. This means that this point shows that the length of working time could only illustrate the growth of working hours (not the specific increase or decrease in the number of workers).

This paper uses the following formula²;

$X_{t+1}=(I-A+m)^{-1 *} Y_{t+1}(1)$

Where $X_{t+1},(I-A+m)^{-1}$, and $Y_{t+1}$ are the matrix of the total output of sectors on the $t+1$ period, the matrix of Leontief inverse, and the matrix of final demand on $t+1$ period, respectively. In this study, $t$ provides an illustration of the first period that is in 2012, as $t+1$ donates the next period. Based on the presented formula, we can show the comparison between the present and future economic trends from the result of calculating and examining the I/O Table (Appendix A). The calculation of the output is based on "whole sector change" and "pure change" conditions; that is to say, the changes of the final demand in either all industrial sectors or specific sectors are addressed.

\section{Results And Discussions}

In the METI data, the share of each sector is as follows; the agriculture, forestry and fishery (Agriculture) $(1,56 \%)$, the mining $(0.07 \%)$, the manufacturing $(17.90 \%)$, the industrial machinery (Ind. Mac.) $(2.82 \%)$, the computers and electronic equipment (Com \& Elc) (4.90\%), the automobiles (Auto.) (5.93\%), the 
construction (Constr.) (5.85\%), the commerce (Comm) (10.84\%), the finance and insurance (Fin \& Ins) (3.81\%), the other business services (Oth. Bus) (4.95), and the services (Serv.) (41.37\%). Secondly, the share of each item is as follows; the private consumption expenditures (PRCE) (52.87\%), the public consumption expenditures (PUCE) (13.61\%), the private gross fixed capital formation (PRGFC) (15.16\%), the public gross fixed capital formation (PUGFC) (3.72\%), the increase in stocks (IIS) $(0.51 \%)$, and the export (14.11\%) in the I/O table.

\subsection{Japan's Economy Analysis Through Leontief Method}

This section examines the economy under aggregation of eleven sectors with the use of $\mathrm{I} / \mathrm{O}$ analysis; to be able to explain together and separately the macro variables by causing the final demand, which is not only invested to but also proportioned to the changes of all the eleven sectors, as well as each sector. That is, this study provides an explanation of the effect of the final demand on the whole sector and to each individual sector.

\subsubsection{Final Demand Changes in Sectoral Basis}

Primarily, all sectors are analyzed through proportional final demand change by $10 \%$. Firstly, this chapter observed the macroeconomic implications of the $10 \%$ increase in the final demand in all sectors. This analysis assumes that a $10 \%$ increment in the total final demand must result in a $10 \%$ increase in macroeconomic variables, associated with if the final demand change by the entire $10 \%$ (Table 1). In other words, the same change in total final demand has to occur as much percentage change as in the macroeconomic variables.

Secondly, the final demand changes reviewed sector-by-sector. According to this notion, for example, the agriculture sector could affect GDP for as little as $0.90 \%$, employment as $0.95 \%$ and import as $0.132 \%$, associated with if the final demand increased by $10 \%$ in the only agriculture sector. On one hand, if $10 \%$ of the final demand increase was only to be implemented in the service sector, and this resulted in an augmentation of growth rate; $4.50 \%$, employment rate; $5.14 \%$, and import rate; $2.58 \%$. Generally, if there was a $10 \%$ enhancement in the final demand in the service sector, growth rate and employment would increase to $4.50 \%$ and $5.14 \%$, respectively, while if there was an increase of $10 \%$ in the final demand in the manufacturing sector, the import rate could immensely escalate by $2.63 \%$ (Table 1 ) .

(Table 1)

Thirdly, we also interpreted the real growth rate of the macro variables based on how much is the percentage change in total final demand (call real change by \%1), instead of final demand increase in a specific sector. For example, if there was a $10 \%$ the final demand increases in the only manufacturing sector contributed total final demand to increase by $1.18 \%$, as well as boosting the growth rate change by $1.20 \%$ and the employment rate change by $0.87 \%$. On the one hand, to reach representing real change/impact, if we divide all the macroeconomic variables change (\%) to the total final demand change (\%), attaining the real changes which account for percentage change of the macro variables 
based on how much the percentage change in total final demand, we can achieve to present real increasement of the macro variables in each sector respectively. As a result, the automobile sector was the important sector for the growth rate $(1.6 \%)$, and commerce was the stronger sector for not only employment (1.3\%), but also import (less effective rate of $0.30 \%$ ); however, the mining sector had an effect of extreme escalation in import rate $(6.68 \%)$ (Table 3$)$.

\subsubsection{Changes in Final Demand's Components}

This section examined the effect of each final demand items (PRCE, PUCE, PRGFC, PUGFC, ISS, and export) on the macro variables as well as on the eleven sectors as a whole (Table 2), as well as each sector individually.

Initially, the data showed that if there was an increase of $10 \%$ in PRCE to all sectors, the growth rate would increase by $5.08 \%$, employment by $5.17 \%$, and import by $4.492 \%$ (Table 2 ). Moreover, a rise in PUCE by $10 \%$ in all sectors affected macroeconomic variables, presenting an increase of growth rate as $1.30 \%$, employment as $1.48 \%$, and import as $0.75 \%$ (Table 2 ).

(Table 2)

In Table 2, it may be inferred that some of the final demand items are an investment, such as PRGFC, PUGFC, and IIS. If PRGFC increased by $10 \%$, there, consequently, would be an increase in the growth rate; that was $1.63 \%$, followed by employment and import with $1.45 \%$ and $1.82 \%$ respectively. Secondly, an increase of $10 \%$ in PUGFC to all sectors was examined. As a result, growth could thrive by $0.41 \%$, followed by employment and import with $0.39 \%$ and $0.32 \%$ respectively. Thirdly, if the increase of $10 \%$ in ISS to all the sectors, the growth rate could boost up to $0.03 \%$, followed by the employment and import rate with $0.04 \%$ and $0.10 \%$ respectively.

Additionally, export had the third-largest percentage in the final demand items with $14.11 \%$. Following the previously mentioned result, it can be concluded that there was a significant correlation between all the sectors and the macro variables in export change. The study was analyzed in an increase of $10 \%$ in the export to all sectors. Accordingly, growth could have an accrual of $1.54 \%$, followed employment and import with $1.12 \%$ and $250 \%$ respectively (Table 2 ).

\subsubsection{Effects of Quantity Increases}

This analysis examined when an entrepreneur invests in each sector and how capital affects macroeconomic variables. That is, this chapter investigated the question of which sector efficiently gain the most profits by investment amount of 1 Billion Yen (BY) (2005 price).

This paper examined to equally invest in all sectors by the amount of $11(\mathrm{X}) 1 \mathrm{BY}$. Accordingly, the growth rate, employment rate, import rate, and final demand rate could totally boost by $1.86 \%, 1.73 \%, 3.35 \%$, and $1.97 \%$ respectively. More specifically, investment in the automobile sector, even share in total production with $5.93 \%$, was the most prominent sector for profit. In other words, if the government spent $1 \mathrm{BY}$, in the automobile sector, the effect on the overall growth would elevate by $0.286 \%$ (Table 3 ). On the contrary, if 
we see the real impact in the growth of the macro variable based on percentage change in total final demand (by $1 \%$ ) so that spending on the automobile sector resulted in the increase of $1.60 \%$ in growth, although spending on mining sector advanced by $0.05 \%$ in growth (Table 3 ).

(Table 3)

Additionally, the impact of spending money on the service sector, especially the commercial sector, was highly correlated with the employment rate; however, it had a low correlation with the import rate. Therefore, if $1 \mathrm{BY}$ was spent on the commercial sector, the effect on employment rate and import rate would rise by $0.23 \%$ and $0.051 \%$ respectively. On the other hand, spending on the commerce sector could have an increase of $1.27 \%$ of employment and $0.28 \%$ of imports while spending on the mining sector would increase employment rate by only $0.05 \%$ and $6.68 \%$ import rate based on real change by $1 \%$ (Table 3).

In addition, according to Chenery and Clark's group $(\mu)^{3}$ classification of backward \& forward linkage, we can also observe that high value of $\mu$ such as automobile and construction sector for backward linkage and manufacture and service sector for forwarding linkage provide considerably critical information that illustrates high/large linkages -usage of intermediate inputs (Appendix 7). This means that policymakers can manage their top priority industries to set an efficient system as a linkage between users and providers of inputs. Therefore, these policies could significantly influence the whole sectors in Japan.

In a nutshell, each of the final demand parts has different dynamics and has a different impact on the macro variables through the different reactions from each sector. Accordingly, the automobile sector was the dominant industry for growth rate, increasing by $1.60 \%$, followed by the commerce sectors for employment rate, with $1.27 \%$. Moreover, whereas the effect of the commerce sector on import rate was the lowest, the mining sector had a large influence on import rate; by $0.29 \%$ and $6.68 \%$ respectively. That is to say, the economic stakeholders should invest in the automobile sector for growth rate, and they should economically orchestrate to invest in the commerce sector if their target is not only employment rate but also minimal import rate in the economy. Another point is that import was highly affected by the computer and electronic equipment sector $(2.75 \%)$ and manufacture sector $(2.22 \%)$ which in turn may make Japanese manufacture an import-dependent market since these variables share $22.8 \%$ in total production (Table 3). For this reason, manufacturing industries (specifically the automobile, industrial machinery, and computer and electronic) should consider checking up on how much is their productions based on import such as either energy-related sources or intermediate commodities, and then they would decrease the reliance of their goods and services on import (Appendix 7).

\section{Strategic Final Demand and Sector}

This section aimed to find out the important/dominant sector through potent final demand items regarding selected the three macro variables and investigated/commented through macro-economic data, from 2000 to 2012. Moreover, this paper drew with some inferences about the position of the prominent sectors based on the data provided. This, therefore, was illustrating an explanation in which 
both, the final demand item and sector, would be selected in term of the targeting macro variables for future economic policy paths; in other words, three scenarios for future economic policy are proposed

\subsubsection{Dominant Final Demand Element}

Generally, each final demand item had a different effect on macroeconomic variables. Hence, this section identifies the extent of the effect of the changes in the final demand components on macroeconomic variables. Regarding the effect of the growth rate, the most effective demand for growth was PUGFC, with 1.11 (Table 5). According to the percentage of PUGFC in GDP, it plummeted from $7.60 \%$ in 2000 to $4.80 \%$ in 2007 and then fluctuated between $4.80 \%$ in 2007 to $4.90 \%$ in 2012, diminishing all by $2.70 \%$ (36\% change). Hence, PUGFC had a negative percentage influence on the GDP from the year 2000 to 2012; however, the opposite can be said only for the years 2009 and 2012, the perspective of contributions to real GDP by the demand. The latter is mainly due to the percent changes from the previous year in the general government and non-resident investment (Table 4; 8; CO, 2018). The rest of the effect of the growth is followed by export $1.09 \%$, PRGFC by $1.04 \%$, PRCE by $0.96 \%$, PUCE by $0.95 \%$, and IIS by $0.58 \%$ respectively (Table 5)

(Table 4)

The second macro variable is the employment rate. PUCE, which induced a considerable shrinkage in the unemployment rate, was, therefore, the most potent demand to achieve an increase in the employment rate. More specifically, it triggered the employment rate to increase by $1.09 \%$ (Table 5). As per the percentage of the PUCE in GDP, it started at $16.90 \%$ in 2000 , and then it remarkably rose to $20.30 \%$ in 2012, albeit with moderated fluctuation (Table 4). After the positive change of the PUCE in GDP, it affected to derogate unemployment rate (partly also depopulation), whereas the PUGFC in GDP, which influences the employment rate as the second one the list, declined. That is, it seems that public investment and consumption were proportionally set balance in order to boost macro variables; to state, while PUGFC decreased, PUCE increased during the last two decades, concerning the percentage of the PUGFC and PUCE in GDP (Table 4; 5).

On the other hand, observed that the impact on the macro variables had a significant correlation with both the PRGFC and PUGFC, but the public budget needs to be reasonably set in an efficient way for fiscal balance, expenditures and tax revenues. If there was a shortage of account in the public budget, reaching a large size of the public budgetary deficits ${ }^{4}$, the government would not implement its public budget to trigger macroeconomic variables to grow by both consumption and investment due primarily to the shortage of its public budget (Chart 1). This paper reviewed the fiscal situation and the depleting economic shock (power) in more detail below in Sect. 4 .

(Chart 1)

According to PRCE, it influenced to drive up not only the employment rate as the third rank but also the growth rate as the fourth rank. It contributed to the employment rate to accelerate by $1.04 \%$ (Table 5). As with the percentage of PRCE in GDP, it began at $54.30 \%$ (2000), and then it marginally increased to 
$58.80 \%$ (2012), albeit with fluctuations. Hence, it helped in the annual increase in the employment rate. It can be observed that while the consumption rate increased, investment fell during the 12 years. It seems that the government implemented merely temporary (short-term) solutions for the situation on employment (Table 4; 6).

(Table 5)

However, export boosted growth (1.09) as the second rank of effect, and it also affected to be an improvement in the employment rate as the fifth rank of effect (Table 5). Concerning the percentage of export in GDP, it increased from $10.70 \%$ in 2000 to $14.70 \%$ in 2012, albeit with fluctuation (Table 4). Accordingly, export stimulated both the employment and growth rate based on the percent change from the previous year (Table 4; 6; 8).

(Table 6)

Another interesting point is that IIS had a minimal effect on both the employment and the growth rate (Table 5). It is known that if investments have an effect in the form of a stock increase or not emerging to a production process, impact on macro variables can be influenced to amplify at the minimum ratio. With respect to imports, IIS had many effects on the import rate amplifying the former by $1.96 \%$ (Table 5).

Thus, either if commodities cannot flow in a market economy, or if goods may accumulate as an increase in stocks - a shortage of the supply side- demand side may possibly apply to buy import products. In short, if at present specific goods and services are unavailable, a consumer may purchase a substitute import-related commodity.

(Table 7)

The second rank of effect on imports was the export, which triggered the import rate to increase by $1.77 \%$ (Table 5). For example, Table 7 highlights that an increase of $10 \%$ in the export to all sectors caused an increase in the import rate $(2.50 \%)$. Specifically, if there was a rise of $10 \%$ in the export, it equaled to 7.9 BY; as a result, the import would increase to $2.0 \mathrm{BY}$. In other words, if there was a rise of $100 \mathrm{BY}$ in the export, it would contribute to the improvement of imports by roughly 26 BY. To state briefly, the export is comparatively highly dependent on import (25.50\%). To add, the percentage of the export in GDP increased from $10.70 \%$ in 2000 to $14.70 \%$, notwithstanding the fluctuation (Table 4). Accordingly, the balance of (international) trade is significantly correlated with net export. Thus, in current Japan's economic structure (in 2019), the government's goal is to support the export industry by weakening the yen and to make a positive net export. Thence, this goal not only does not work to reduce the import ratio but also could cause higher energy costs and other intermediated import commodities for small- and medium- entrepreneurs (SME) to easily fail (Aoyagi \& Ganelli, 2015). The weak yen policy and its relation to Abenomics are discussed in more detail below in Sect. 4 .

(Table 8) 
If we look at the investment, the PRGFC and PUGFC had a different impact on the import rate, with $1.20 \%$ and $0.87 \%$ respectively. This means that the PRGFC was stimulating more on import rate than in the PUGFC. Similarly, PRCE and PUCE had a different effect on the import rate, with $0.85 \%$ and $0.56 \%$ respectively. It is true that the preference for PRCE was more on the import-related goods and services than in the PUCE. The final point to stress is that not only did the PUCE, which was less dependent on import demand, tend to purchase more domestic products, but it also demanded to consume more laborintensive commodities (Table 5).

\subsubsection{Prominent Sector}

This part provided an explanation of the strategic sectors through a dominant final demand element. Moreover, the strategic sector, which has multiple effects on the other sectors and remarkably stimulates the overall macroeconomic variables, was evaluated through macroeconomics data, from 2000 to 2012 as well. Here we also eventually built the information and background of the three scenarios based on the targeting macro variables.

In addition, before reviewing the analysis it is also crucial to check sectoral output sufficiency for its total domestic demand out. Literately, the self-sufficiency rates (SSR) ${ }^{5}$ for Japanese sectors provide an explanation of total production to total domestic demand (except for export). Which means that the Japanese economy in 2012 was needed to meet import before meeting its domestic demand due to the overall average SSR (0.9596). Especially, extraordinarily low SSR (0.0422) for the mining sector in Japan is due to the heavily dependent import on energy. On the other hand, automobile and industrial machinery represent high SSR because of foreign demand (export) (Appendix 6).

(Table 9)

Since the PUGFC was a growth-related dominant demand (Table 5), this study investigated which sector was to have a considerable influence on the growth rate by either consuming or investing through the PUGFC. Thus, the most important industry and robust sector to promote growth was the automobile sector which evidently and significantly triggered the overall growth rate to advance by $1.60 \%$ through the PUGFC (Table 11), as one of the three arrows was proposed to promote sustainable growth by expanding the productivity rate so that this policy would consider as a key factor to reach the nominal GDP of 600 trillion yen. Also, in perspective of the near future of the automobile sector may help to promote the computer and electronic equipment sector to be a productive sector because of the sectoral connection. In general, the more policymakers and investors invest/subside heavily in the specific sector, the less the sector would be productive regarding sustainability and the more it may cause the market to destabilize (becoming boom sector) under the competitive market assumption (Balkyte \& Tvaronavičiene, 2010; Flanagan, et al., 2007). Therefore, they should consider managing their capital in the sectoral base productivities and sectoral interlinkage/connection if they aim to make a sustainable growth/profit.

For example, after investing $1 \mathrm{BY}$ in automobile sector, the overall growth rate would increase by $0.286 \%$ as well as regarding the multiplier effect of the automobile sector to other sectors such as promoting the 
manufacturing $(0.195 \%)$, the computers and electronic equipment $(0.177 \%)$, and there are also high value of $\mu$ such as automobile and construction sector for backward and manufacture and service sector for forward (Appendix 7). Hence, it is observed that the Japanese automobile sector was significantly correlated with construction, manufacturing, service, and computer and electronic sectors. In addition, the percentage of the automobile in gross fixed capital formation fluctuated between $1.16 \%$ in 2000 and $1.12 \%$ in 2012 , decreasing by $0.04 \%$, whereas the public capital investment in the machinery and equipment raised from $8.60 \%$ in 2000 to $11.73 \%$ in 2012, albeit with fluctuation (Table 10). Therefore, the automobile sector under the manufacturing sector contributed to enhancing GDP from 2000 to 2012, associated with its data from the previous year (Table 9). Evidently, other sectors were stimulated by the automobile sector, which considerably produced added value and had multiplier effects. It might have invigorated to GDP more than its impact on the calculated GDP.

(Table 10)

With respect to the employment dependent sector, PUCE by either consumption or investment had a considerable effect on the employment rate (Table 5). As a result, there was an accrual in the commercial sector which fostered the employment rate to increase by $1.27 \%$ through the PUCE (Table 11). Briefly, the manufacturer has been automating their operation, yet the service-related market is still relying mainly on workers (Appelbaum, et al., 2000). Another interesting point is that after creating Al, significant numbers of analysts have discussed whether or not there will be a need to hire people (workforce) because of the automation, especially artificial intelligence, which means Al would replace many work passions such as mainly large number of middle-class jobs. Therefore, as Marx and Keynes have pointed out workless futures, this progress would either cause the negative effects on unemployment and inequality or build the opportunity to extend the free time that employees could enjoy spending out of working time with their families, hobbies, and educations if they are salaried without working (Etzioni, 2017; Pugliano, 2017; Spencer, 2018). We do not discuss the IT impact on a market in this paper, but it must be considered.

Lastly, the import-based demand was the IIS, which had a significant effect on the import rate to increase by $1.96 \%$, whereas PUCE let efficiently and comparatively in reducing the growth import rate, with $0.56 \%$ (Table 5). Accordingly, commerce affected import the lowest, with $0.28 \%$, while the mining sector has a significant influenced on import rate (6.69\%) through PUCE (Table 3).

(Table 11)

To put it briefly, the government mostly either invested or consumed in the service sector (mainly social welfare) (Table 4) and this policy inefficiently encouraged/promoted the weak sector, instead of the dominant automobile and commerce sectors in order to boost the growth and employment rate (Table 8; 11). Another challenge of the Japanese economy in the near future is investigating an only sector or managing capital in all sectors regarding the backward and forward linkages. Thence, if the Japanese government sought to improve their productiveness in the national market as one of three arrows aims, there are, therefore, two most likely policy choices; either they could still invest their dominant automobile/commerce sector to invigorate GDP/employment rate or they should consider not only 
subsidizing the weak sectors such as computer and electronics sector but also how their sectors reduce import ratio (Table $5 ; 7 ; 11)$ for the goal of the creating an environment to be an innovative and productive country.

\section{Evaluation Of Abenomics}

Prime Minister Shinzo Abe elected in December 2012 delivered a speech about his economic strategy policy (Abenomics) to the National Diet in January 2013. Abenomics is comprised of three key factors; three arrows, in which it represents a mix of the new Keynesian remedies in the financial and monetary policies and the neoliberal policies in terms of the structural reform (especially employees).

The first arrow is the monetary policy, which aims to achieve a $2 \%$ inflation target, is able to deal with the long-term deflation. The recent strategy is proposed to promote sustainable growth by expanding the productivity rate so that it will reach the nominal GDP of 600 trillion yen.

The second arrow is the flexible fiscal policy, which is a short-term policy seeking to promote the GDP and accomplish a budget surplus by raising the tax ratio. Moreover, this approach is also focused on handling age-related issues with the intent to increase the fertility rate to 1.8 percent as well. To achieve this the Japanese government is subsidizing childcare centers which will enable women to work while leaving their child in care centers. As of 2019, the government had subsidized infrastructure projects, such as bridges, tunnels, and earthquake-resistant roads (GOJ, 2019).

The third arrow is a growth strategy, which is a long-term growth plan that focuses on the structural reform and the private sector investment to acquire an annual increase of $+3 \%$. To add, this policy includes the plan in liberating the labor market (more flexible labor market) and more market-based agricultural sector, cutting corporate taxes, encouraging venture capital for domestic and international, and stimulating innovation through technology (GOJ, 2019).

Explicitly, the three-arrow policy boosted the productivity growth, thus creating a business-friendly environment, which not only helps weaken of the keiretsu network (a financially independent network of Japanese businesses that closely work together) through integrating with the international market but also made a more competitive international market (Lechevalier \& Monfort, 2018). The innovations were triggered by the realization that the technological level of the Korean, Chinese, and Taiwanese companies have been at par with the Japanese companies.

Basically, Japanese economic growth is based on domestic demand (roughly 80\%) (Table 4; 8) and vigorous reasonable economic policy. Hence, the Japanese market economy has been evaluated to increase its trust index due to the national and international supporter (by OECD, IMF, and Krugman) (Shibata, 2017); moreover, the world growth has arisen since Abe took office as the Prime Minister of Japan on December 2012. This means that under the positive environment of politics, the announcement effect, and world growth: these have led to the improvement of Japan's production rate (Lechevalier \& Monfort, 2018). Moreover, the Japanese government under Abe administration has a strong role 
especially in Southeast Asia through the Comprehensive and Progressive Agreement for Trans-Pacific Partnership (CPTPP) and has taken to wave the free trade flag, especially nowadays with the withdrawal of the United States under the new Trump-led government (Urata, 2018). Further, Japan and the European Union finally signed the Economic Partnership Agreement (EPA) entering into force on February 1, 2019, which has been becoming the world's largest bilateral free trade based on trade zone covering nearly onethird of global GDP (Boffey, 2018). Therefore, Japan's economy has many good chances to invigorate its GDP if the government considers solving some of its domestic problems and preparing its economy to be competitive internationally.

\subsection{Potential Risk}

First and foremost, Japan's primary problem is its debt level, which illustrated the debt to GDP from about 120 percent in 1999 to approximately 240 percent in 2017. This means that the Japanese debt was double as in Euro countries and the USA (MOF, 2018). Because the IMF frequently advised reducing the level of the debt, the Japanese market may, therefore, lose its credibility (IMF, 2016). Moreover, Chart 1 highlights that accumulating Japanese bonds ${ }^{6}$, which was mostly a saving or investment of Japanese citizens, might destabilize the domestic demand if they believe Japanese cooperation profit decrease, they, in turn, might switch from the Japanese bond to other assets, so this process makes Japanese bond value decrease cause the Japanese economy to face financial crisis and hyperinflation. The main reason for this is that "Japan's debt sustainability depends on whether or not the entire market's belief that it will become sustainable" (Armstrong \& Okimoto, 2016; Auerbach, 2016). On the other hand, orthodox/conventional economists argue that the high debt level will not necessarily cause high inflation or bankruptcy such as Japan because "fiscal policy works, and monetary easing doesn't". However, according to a 2019 NHK report, many young people in Japan seriously worried about their future retirement, public pension, and healthcare systems because the public debt, which is expected to increase, was too high and not sustainable due to a rapidly aging population and shrinking workforce (Noguchi, 2019). This fear would have an impact on those who have felt austerity and have spent as little as possible have caused GDP growth to stagnate.

Additionally, the second problem is that the Japanese government either consume or invest much more in the service sector, and expectation of the medical care expenditure would increase for future, especially social welfare (Table 4). Therefore, this policy presented that the ratio of the social security spending in GDP was much higher than the ratio of the tax burden and social security contribution in GDP (Armstrong et al., 2016). These may destabilize not only the primary balance (expenditure $>$ tax revenue) but also the productive/dominant sectors. More specifically, if the government either subsidizes or encourages public health-related companies, which are not as productive/key sectors as the automobile/commerce sector (Table $3 ; 11$ ); they might affect a prominent sector to not effectively boost its macro variables. They may, therefore, leave behind the technological trend, because Japanese people may not opt to work for the manufacturing industries due to relatively low wages and income because if they work in the service sector (especially public health/social welfare) they earn more money (Chart 2). The economic practice which the society has been traditionally doing could not change easily and it is (not) the sustainable 
development if the policy keeps heavily subsidizing/investing the service sector might not be the more profitable sector as compared to the others (Table 11).

(Chart 2)

Particularly, the first arrow is composed of the aggressive monetary policy and the negative interest rate, which have caused in the creation of a suitable atmosphere for a citizen who can buy a house; in contrast, mainstream economists criticize that the form of ultra-low interest rates and unconventional monetary policy for a decade (theoretically and practically) causing interest rates to unexpectedly rise would lead to hyperinflation and have destabilized the shock (power) to stabilize and stimulate the economy because of lack of structural reforms. Meaning neither has this cured the problems nor helped lack demands. Instead, this not only would cause an increase in asset price but also could make consumer suffering so that the collapse of asset-price bubbles will trigger another economic crisis in the economy. Moreover, Baak (2017) pointed out that the yen was undervalued and misaligned during the Abenomics period. The weak yen policy, which promoted the export industry (mainly the automobile sector), led to, however, the increase of the cost of import goods because the market is heavily dependent (roughly 95\%) on oil, coal, and natural gas (Lu et al., 2016). Consequently, trade balance and SME have been destabilized because of the depreciation of yen since the 2011 Japanese nuclear accident (Vivoda, 2016). This is the paradox that while encouraging export, the government has sacrificed the SME, which domestically build the technology and innovation sector.

\subsection{Possible Solution to Reinvigorate Japan's Economy}

Initially, the economy needs to have credible economic structural reforms and judiciously a robust/smart economic policy in the near future in terms of the balance between government consumption and tax revenue. Thus, the government should increase either its tax revenue or reduce its expenditure to achieve a fiscal surplus. One option is that the consumption tax should increase to $30 \%$ or $36 \%$ to accomplish the fiscal sustainability, associated with the primary surplus in 2020 (Braun \& Joines, 2015; Oshio \& Oguro, 2013). It can be observed that after the consumption tax hiked from 5-8\% in 2014, it resulted in the decline of GDP growth to below zero (Table 8). As a short-term remedy, after the tax increase, the government should first increase its expenditure (up to as much as the tax revenue change/gaining) either to invest in the dominant sector to accelerate the growth rate or to consume in the prominent sector to invigorate employment rate and reducing import rate (Table 11). The classical approach of hiking taxes, however, control and reduce the inflation rate while the government aims to increase inflation so that the second/main challenge in increasing the tax is that the reduction of the real salaries especially for low or middle incomes might not buy enough commodity as much as they used to. It is strongly suggested that especially the lower (at least/minimum salary is to reach (more than) $¥ 200.000$ ) and middle wages be augmented at the least as much as the increase in the tax rate. In other words, the equal increase in the tax rate and wages would invigorate not only the consumption but also the fiscal sustainability (Arnold, 2008). The real wages line has significantly cointegrated with the consumption of household line (BOJ, 2018; CO, 2018). The more increase in the real wages, the more improvement in consumption, growth rate, and tax revenue there would be. 
In addition, the labor market legislation, which the parliament has published, has worked out overtime work, ensure equal treatment for regular and nonregular workers, and exempt skilled professional workers from working-hour regulation because the Japanese market needs workforces; especially, more workers with success with women, older workers, and inflows of foreign labor- into the labor force would be a possible solution to the aging-related labor shortage problem and contribute household income/consumption. However, it is still the problem of the new law's implementations/effectiveness in the market such as Japan ranked 110 out of 149 countries based on the World Economic Forum's latest Global Gender Gap Index (WEF, 2018) whereas even the Abe-led government has supported female workers (womenomics) and broader labor reforms since 2013. Also, real wage growth has not enhanced its efficiency for encouraging unemployment people to work. For example, regular worker's salary reached an increase of $0.6 \%$ and non-regular workers, $38 \%$ in the labor market, however, shrank by $0.7 \%$ because of increasing the flexible working hours (Shibata, 2017). On the other hand, the deregulation policy, the third arrow, wants a flexible working practice which aims to deregulate and liberalize the labor market. In short, the structural reform for the labor market has built an inappropriate/insecure environment especially for the non-regular workers, whose incomes have been performance-based and hourly-based. Also, this could make the regular/non-regular workers to overwork.

The other challenge is that while reducing the corporate tax benefits for the capital and SME, increasing the consumption tax may lead to only burden the workers to handle the fiscal deficit. Thus, this policy could destabilize the society (social texture) and the consumption balance and then could cause an increase in the poverty level and their Gini ratio (Lechevalier \& Monfort, 2018). Thomas Piketty (2014) has pointed out that a sudden increase in income inequality-causality has yet (difficult) to be proven- is often followed by a great crisis (Vallier, 2019). If the government's goal is to achieve $2 \%$ inflation and GDP growth, they should consider how much consumption contributes to the GDP and inflation (Table $4 ; 8$ ). Subsequently, people tend to either spend or save their money based on their economic status; whether or not they not only feel secure in accordance with their job but also have enough money for their cost of living (despite their location of residence). Questioning the classic Japanese working system such as on long-term employment and seniority system would help to solve that problem (Porter, Takeuchi, \& Sakakibara, 2000). To put it briefly, policymakers should consider their social structure of working practice because if there are sudden changes in the economic structure ${ }^{7}$, it would negatively impact on all society. Otherwise, the government might face many problems such as an increase in the poverty rate, shortage of domestic demand, lack of consumption, and the lack of balance between their obligations at work and their families.

In nutshell, the government has stated that the SME was very important to reinvigorate the economy because the Korean, Chinese, and Taiwan export companies have become competitive. To reach a high comparative market and build an environment for IT, there is a probability that the manufacturing industries (especially automobile and electronic and computer) not only might be able to build an opportunity for the Al (Stiroh, 1998; Flanagan et al., 2007) but also would relatively become a more productive sector to internationally compare with (Table 11). In the near future, the private owner and 
government should consider how the manufacturing industries reduce import dependency (Table 7) and how to invigorate the weak electronic and computer sector, especially digital devices, for them to become a competitive export sector. On the other hand, Aoyagi and Ganelli (2015) pointed out that weak yen policy could cause higher energy costs and other intermediated import commodities for SME, while the government's plan subsidized the SME by reducing corporate tax to create more technological and innovative sector. Especially, after the 2011 Japanese nuclear accident caused by the earthquake in Fukushima, the trade balance has been negatively affected and then the CPI line has become parallel to the energy line (BOJ, 2018; CO, 2018). To put it simply, the government should stop implementing weak yen policy, which leads to the increase of the cost of energy and import related goods and services, and instead, they should also invigorate subsidizing the weak manufacturing industries based on the results of the data analyzed $($ Table $1 ; 2)$ in order to relatively become innovative and competitive export sectors/economy.

\section{Conclusion}

This paper empirically studied the Japanese economy by applying the updated 2012 domestic I/O table, investigated comparing with Abenomics in order not only to understand the current economic structure but also to evaluate comparatively the recent economic policy, and provided some discussion to figure out in perspective of how to solve some economic issues in Japan.

Firstly, based on the results of the data analyzed, each of the final demand has different dynamics and has a different impact on macro variables through different reactions from each sector so that the public investment and expenditure are, in turn, the dominant figures in the economy. Accordingly, the strategic final demand and sector in term of the selected/targeted macro variables represented three scenarios: the target of the growth rate -the automobile sector through PUGFC-, the employment rate -the commerce sector through PUCE-, and the import rate -the commerce sector through PUCE (Table 11). Also, manufacturing (containing automobile and industrial machinery) and service (including other business and commerce) sector should go hand by hand due to the backward and forward linkages (Appendix 7).

Secondly, we examined the current economic structure and Abenomics through cabinet office data and 2012 domestic $\mathrm{I} / \mathrm{O}$ analysis. As a result, these results suggest that policymakers should consider the manufacturing, automobile, industrial machinery, and computer and electronics sectors (instead of the social welfare-related companies) as its key sector for the benefit of the IT industry. That is, the policymakers should reconsider organizing their economy in order to become either a more innovative country regarding the automobile, industrial machinery, and computer and electronic sectors or a service country based on the service sector. Moreover, the Japanese government should strengthen yen because if otherwise is done; it may cause the increase in the costs of energy and import-related commodities, especially for SME.

In addition, many mainstream (orthodox and unorthodox) economists have, qualitatively and quantitively, criticized Abenomics and argued supply-side remedies of a mix of the new Keynesian in the 
financial and monetary policies and the neoliberal policies in terms of the structural reform (GOJ, 2019). Accordingly, their main results highlighted that those policies not only have caused an insecure environment for employees due to the deregulate working system but could also destabilize policy shock (power) to stabilize and stimulate the economy through fiscal deficit, making younger generations fearful about their future (Noguchi, 2019); and hyperinflation - an increase in asset-price (Armstrong \& Okimoto, 2016; Shibata, 2017; Lechevalier \& Monfort, 2018). Thereafter, this study, thirdly, suggested some possible policy paths based on the demand-side remedies which account for Keynesian-inspired Japanese economic policy to resolve the economic issues; structural reforms in fiscal sustainability, mainly wage increase (especially low and middle incomes), working practice, and fair tax system.

Indeed, the results of the study also showed that the focus should not only be on the economic sectors but also on the welfare of Japan's workforce; that is mutual work environment to encourage demand-side remedy for the economic issues. if the government judiciously implements some of the proposed/smart economic policy or three arrows, they should critically consider their current economic structure, and accordingly, what needs to be performed to be able to set an efficient solution based on their economic goal.

\section{Endnotes}

${ }^{1}$ According to the Fisher theory $\left(r=i-\Pi^{e}\right)$ (Taylor, 1993) the real interest rate is positive $(r>0)$ because of negative inflation.

2 Comparative and noncompetitive equation are well illustrated in 4.7.5 section of Miller and Blair (2009).

3 The ratio of the sum of the column/row of the Leontief inverse to the average of the entire system (Rasmussen, 1957).

4 General government gross debt(in \% of GDP) increased from 164 in 2002 to 253 in 2017. General government net debt to GDP increased from 74.5 in 2002 to 130 in 2017 (MFO, 2018).

$5 \mathrm{SSR}>1$ is a sector sustain for its domestic demand whereas $\mathrm{SSR}<1$ is a sector rely on import demand for its domestic demand (Kwangmoon, Trinh, \& Kaneko, 2010)

${ }^{6}$ The government bond was held by 10 percent foreign bonds and 90 percent domestic bonds in 2016 (MOF, 2018).

7 The government has started implementing liberal policy in the labor market to become flexible labor since 1990 (Shibata, 2017).

\section{References}

Akamatsu, K. (1962). A historical pattern of economic growth in developing countries. The Developing Economies, 1, 3-25. doi:10.1111/j.1746-1049.1962.tb01020.x 
Aoyagi, C., \& Ganelli, G. (2015). Labor market reform: Vital to the success of Abenomics. Can Abenomics Succeed, 107-124?

Appelbaum, E., Bailey, T., Berg, P. B., Kalleberg, A. L., \& Bailey, T. A. (2000). Manufacturing advantage: Why high-performance work systems pay off. Cornell University Press.

Armstrong, S., \& Okimoto, T. (2016). Fiscal sustainability in Japan. Asia \& the Pacific Policy Studies, 3(2), 235-243. doi:10.1002/app5.133

Arnold, J. (2008). Do tax structures affect aggregate economic growth?

Auerbach, A. J. (2016). Long-term fiscal sustainability in advanced economies: Fiscal sustainability in economies. Asia \& the Pacific Policy Studies, 3(2), 142-154. doi:10.1002/app5.131

Baak, S. (2017). Is the yen misaligned more during the Abenomics period? Japan \& the World Economy, 44, 26-34. doi:10.1016/j.japwor.2017.10.004

Balkyte, A., \& Tvaronavičiene, M. (2010). Perception of competitiveness in the context of sustainable development: Facets of "sustainable competitiveness". Journal of Business Economics and Management, 11(2), 341-365.

Bank of Japan (BOJ). (2018). Outlook for economic activity and prices. 0. https://www.boj.or.jp/en/mopo/outlook/index.htm/: 2018.

Boffey, D. (2018, Tue 17 Jul 2018 14.19 BST). Japan-EU trade deal 'light in the darkness' amid trump's protectionism. The Guardian, pp. https://www.theguardian.com/world/2018/jul/17/japan-eu-trade-deallight-in-darkness-amid-trumps-protectionism.

Botman, D. P., Danninger, M. S., \& Schiff, M. J. A. (2015). Can Abenomics succeed? Overcoming the legacy of Japan's lost decades International Monetary Fund.

Braun, R. A., \& Joines, D. H. (2015). The implications of graying Japan for government policy. Journal of Economic Dynamics and Control, 57, 1-23. doi: 10.1016/j.jedc.2015.05.005

Cabinet Office (CO). (2018). Cabinet office home page. Retrieved from http://www.cao.go.jp/index-e.html Clark, P. G., \& Chenery, H. (1959). Interindustry economics New York, NY, John Wiley \& Sons Incorporated.

Etzioni, A. (2017). Job collapse on the road to new Athens. Challenge, 60(4), 327-346.

Flanagan, R., Lu, W., Shen, L., \& Jewell, C. (2007). Competitiveness in construction: A critical review of research. Construction Management and Economics, 25(9), 989-1000.

International Monetary Fund (IMF) (2016). Japan: 2016 article IV consultation-press release; and staff report. (No. Country Report No. 16/267). doi:9781475522105/1934-7685 
Ito, T., Iwata, K., McKenzie, C., \& Urata, S. (2018). Did Abenomics succeed? Editors' overview. Asian Economic Policy Review, 13(1), 1-22.

Kuroda, M., \& Nomura, K. (2004). 15 technological change and accumulated capital: A dynamic decomposition of Japan's growth. Wassily Leontief and Input-Output Economics, 256.

Lechevalier, S., \& Monfort, B. (2018). Abenomics: Has it worked? will it ultimately fail? Paper presented at the Japan Forum, 30(2) 277-302.

Lu, H., Campbell, D. E., Sagisaka, M., \& Ren, H. (2016). Interactions among energy consumption, economic development and greenhouse gas emissions in japan after world war II. Renewable and Sustainable Energy Reviews, 54, 1060-1072.

Makita, T. (2017). Japan's economic outlook and challenges for 2020 and beyond. (). https://www.jri.co.jp/english/periodical/jrirj/: JRI Research Journal.

McGuckin, R. H., \& Stiroh, K. J. (1998). Computers can accelerate productivity growth. Issues in Science and Technology, 14(4), 41-48.

Miller, R. E., \& Blair, P. D. (2009). Input-output analysis: Foundations and extensions, second edition doi:10.1017/CB09780511626982

Ministry of Economy, Trade, and Industry (METI). (2018). Updated input-output table. 2012 input-output table Retrieved from http://www.meti.go.jp/english/statistics/tyo/entyoio/index.html

Ministry of Finance (MOF). (2018). Retrieved from https://www.mof.go.jp/english/index.htm.

Mino, K. (2016). Fiscal policy in a growing economy with financial frictions and firm heterogeneity. The Japanese Economic Review, 67(1), 3-30.

Miyao, R., \& Okimoto, T. (2017). The macroeconomic effects of Japan's unconventional monetary policies. Research Institute of Economy, Trade, and Industry (RIETI),

Morita, H. (2017). Effects of anticipated fiscal policy shock on macroeconomic dynamics in japan. The Japanese Economic Review, 68(3), 364-393.

Ning, Z. (2018). Is there a new debt crisis on the horizon? Retrieved February 3, 2019, from World Economic Forum website: https://www.weforum.org/agenda/2018/09/is-there-a-new-debt-crisis-on-thehorizon/.

Ning, Z. (2018, September 12). Is there a new debt crisis on the horizon? Retrieved February 3, 2019, from World Economic Forum website: https://www.weforum.org/agenda/2018/09/is-there-a-new-debt-crisison-the-horizon/. 
Noguchi, S. (2019). Is Japan a "model" for modern monetary theory? I NHK WORLD-JAPAN News. Retrieved July 8, 2019, from https://www3.nhk.or.jp/nhkworld/en/news/backstories/593/? fbclid=IwAR0sSw6zXoiAH-wgXrpIQj64kizsLOq3XJhS80n2ephv1fPcdmMgd3yJ2xs.

Oshio, T., \& Oguro, K. (2013). Fiscal sustainability under an aging population in Japan: A financial market perspective. Public Policy Review, 9(4), 735-750.

Porter, M. E., Takeuchi, H., \& Sakakibara, M. (2000). Can japan compete? Macmillan London.

Pugliano, J. (2017). The robots are coming: A human's survival guide to profiting in the age of automation. Ulysses Press.

Rasmussen, P. N. (1956). Studies in inter-sectoral relations. North-Holland.

Shibata, S. (2017). Re-packaging old policies?'Abenomics' and the lack of an alternative growth model forJapan's political economy. Paper presented at the Japan Forum, 29(3) 399-422.

Shishido, S. (2004). 16 Japan's economic growth and policy-making in the context of input-output models. Wassily Leontief and Input-Output Economics, 294.

Shishido, S., \& Nakamura, O. (2019). Growth alternatives of the Japanese economy: Structure and simulations of the dynamic econometric model with the input-output system (demios). World Scientific.

Solis, M., \& Urata, S. (2018). Abenomics and japan's trade policy in a new era. Asian Economic Policy Review, 13(1), 106-123.

Spencer, D. A. (2018). Fear and hope in an age of mass automation: Debating the future of work. New Technology, Work and Employment, 33(1), 1-12.

Stiroh, K. J. (1998). Computers, productivity, and input substitution. Economic Inquiry, 36(2), 175-191.

Taylor, J. B. (1993). Discretion versus policy rules in practice. Paper presented at the Carnegie-Rochester Conference Series on Public Policy, 39195-214.

The Government of Japan (GOJ). (2019). The government of Japan. Retrieved from https://www.japan.go.jp/abenomics/index.html

Urata, S. (2018). The trans-pacific partnership: Origin, evolution, special features, and economic implications. Journal of Southeast Asian Economies (JSEAE), 35(1), 22-38.

Vallier, K. (2019). Rawls, piketty, and the critique of welfare-state capitalism. The Journal of Politics, 81(1), 142-152. doi:10.1086/700108

Vivoda, V. (2016). Energy security in japan: Challenges after fukushima Routledge. 
Yamada, G., \& Imanaka, Y. (2015). Input-output analysis of the economic impact of medical care in Japan. Environmental Health and Preventive Medicine, 20(5), 379-387. doi:10.1007/s12199-015-0478-y

Yoshikawa, H., Aoyama, H., Fujiwara, Y., \& lyetomi, H. (2015). Deflation and money. VOX CEPR's Policy Portal Http://www.Voxeu.org/article/deflation-and-Money,

Zuhdi, U. (2015). An application of input-output analysis in analyzing the impacts of final demands change on the total outputs of Japanese energy sectors: A further study. Paper presented at the Journal of Physics: Conference Series, 622(1) 012041.

Zuhdi, U., \& Prasetyo, A. D. (2014). Examining the total output changes of ICT sectors of Japan: An approach of input-output. Procedia-Social and Behavioral Sciences, 109, 659-663.

Zuhdi, U., Prasetyo, A. D., \& Putranto, N. A. R. (2014). Analyzing the changes in the total output of Japanese livestock sector: An input-output approach. Procedia-Social and Behavioral Sciences, 109, 649653.

Zuhdi, U., Prasetyo, A. D., \& Sianipar, C. P. M. (2013). Analyzing the dynamics of the total output of Japanese creative industry sectors: An input-output approach. Procedia Economics and Finance, 5, 827835.

\section{Tables}

[Please see the supplementary files section to view the tables.]

\section{Conflict Of Interest}

The author declares no competing interests.

\section{Supplementary Files}

This is a list of supplementary files associated with this preprint. Click to download.

- Appendix.docx

- Tables.docx 